Article

\title{
Fractionated Antioxidant and Anti-inflammatory Kernel Oil from Torreya fargesii
}

\author{
Xianrong Zhou *, Jin Shang, Mingyi Qin, Jianhua Wang, Bo Jiang, Hui Yang and Yan Zhang \\ School of Advanced Agriculture and Bioengineering, Yangtze Normal University, Fuling 408100, Chongqing, \\ China; shangjin2017@outlook.com (J.S.); mingyiqin2018@outlook.com (M.Q.); \\ jianhuawang2017@outlook.com (J.W.); BoJ2015@163.com (B.J.); hyytnu@outlook.com (H.Y.); \\ Yanzhang123@163.com (Y.Z.) \\ * Correspondence: zhouxianrong@yznu.cn
}

Received: 8 August 2019; Accepted: 16 September 2019; Published: 19 September 2019

check for updates

\begin{abstract}
Polymethylene-interrupted polyunsaturated fatty acids (PMI-PUFAs) are emerging functional lipids with proven antioxidant and anti-inflammatory effects. In this study, a typical PMI-PUFA, sciadonic acid (C20:3, 5c 11c 14c), was enriched in the kernel oil of Torreya fargesii (T. fargesii) by fractionation. Fractionated kernel oil of T. fargesii (containing $25 \%$ sciadonic acid) showed equal stability and similar radical scavenging ability compared with the non-fractionated oil. In anti-inflammatory tests, fractionated kernel oil was shown to inhibit the activity of phosphodiesterase (PDE-5, efficiency $80 \%$ at $133.7 \mu \mathrm{g} / \mathrm{mL}$ ) and lipoxygenase-5 (LOX-5, efficiency $65 \%$ at $66.7 \mu \mathrm{g} / \mathrm{mL}$ ) more effectively than the non-fractionated oil. This shows that increasing the amount of sciadonic acid can enhance the anti-inflammatory effect of the kernel oil. This research also indicates that fractionation is a feasible way to obtain sciadonic acid-rich functional oil with potential pharmacological effects.
\end{abstract}

Keywords: Torreya; kerneloil; sciadonic acid; antioxidant effect; anti-inflammation

\section{Introduction}

Polymethylene-interrupted polyunsaturated fatty acids (PMI-PUFAs) refer to a series of unusual fatty acids that are different from normal $\Delta_{3} / \Delta_{6} / \Delta_{9}$ PUFAs. PMI-PUFAs have a unique structure of two or more double bonds (in cis-configuration) separated by at least one polymethylene group [1]. Natural PMI-PUFAs include pinolenic acid (C18:3, 5c 9c 12c), sciadonic acid (C20:3, 5c 11c 14c), $\Delta_{7}$-eicosatrienoic acid (C20:3, 7c 11c 14c), and juniperonic acid (C20:4, 5c 11c 14c 17c) (Figure 1). In commercial applications, fat with pinolenic acid was used as an ingredient in diet food [2] and structured lipids [3]. At an academic level, Pedrono found that sciadonic acid has anti-hypertriglyceridemic effects due to its ability to inhibit on $\Delta_{9}$ desaturase [4]. Similar studies showed that sciadonic acid can reduce rats' serum and liver triacylglycerol levels [5]. Huang and Chen [6,7] found that sciadonic acid has a strong anti-inflammatory ability; the mechanism may be inhibition of COX-2activity or reduction of pro-inflammatory mediators. It is still of value to determine further properties of the anti-inflammatory activity of sciadonic acid. 


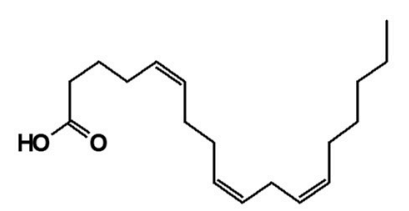

(5Z,9Z,12Z)-octadeca-5,9,12-t pinolenic acid

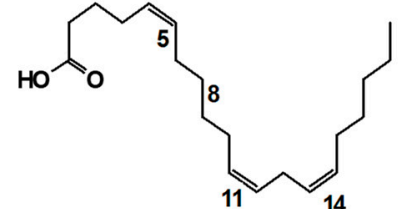

(5Z,11Z,14Z)-eicosa-5,11,14,trienoic acid sciadonic acid $(\Delta 5)$

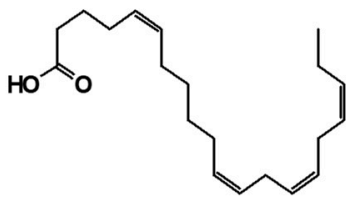

(5Z,11Z,14Z,17Z)-Icosa-5,11,14,17-tetraenoic acid juniperonic acid

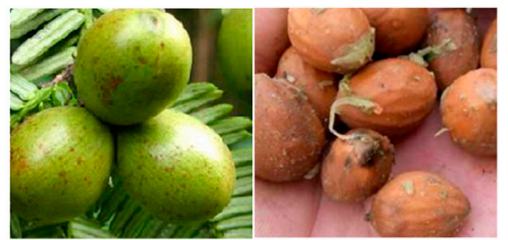

S eed (left) and keme1 (right) of Tome ya farges it

Figure 1. The typical polymethylene-interrupted polyunsaturated fatty acids (PMI-PUFA) and seed of Torreyafargesii.

PMI-PUFAs are found in the kernels of gymnosperms $[8,9]$ such as Podocarpaceae, Pinaceae, and some Taxaceae plants. Torreya is a genus of Taxaceae. Torreya grandis cv. merrillii (T. grandis) is mainly distributed in Southeast China.Its kernel oil contains about 10-13\% sciadonic acid [10-12]. Recently, several studies reported that kernel oil of $T$. grandis has strong antioxidant activity in radical scavenging tests [13-15]. Torreya fargesii (T. fargesii) is an endemic species that grows in the mountainous areas of Central and Southwest China. The botanical classification and ecological habit of T. fargesii differ from those of T. grandis [16]. Our previous work [17,18] indicated that flavonoids or polyphenols extracted from the arils of T. fargesii have antioxidant activity. However, studies of kernel oil from T. fargesii are scarce compared to studies of T. grandis.

The content of PMI-PUFA contributes to the pharmacological activity and nutritional value of Torreya oil and its final commercial products [6,7]. We noted that the kernel oil of Torreya species contains about $10 \%$ saturated fatty acid and $20 \%-30 \%$ monounsaturated oleic acid [11,12], which is suitable for concentrating their unsaturated fatty acids by fractionation. In this work, we investigated the use of conventional methods of fractionation to produce Torreya oil with high anti-inflammatory activity. The stability and antioxidant efficiency of fractionated (FT) and nonfractionated (UT)kernel oil of T. fargesii was tested by heating acceleration, DPPH, and Oxygen Radical Absorbance Capacity (ORAC) tests. We also studied the activity of the kernel oil on inflammatory-related phosphodiesterase (PDE-5) and lipoxygenase-5 (LOX-5) for the first time.

\section{Result and Discussion}

\subsection{Kernel Oil of T. fargesii and its Properties}

The total lipid content in the T. fargesii kernels was $50.3 \pm 2.6 \%$. The oil content in the T. grandis kernels ranged from $45 \%$ to $55 \%$ depending on the growth region [10-12,14]. The oil content of the kernels was comparable to that of rapeseed and sunflower seed (about 35-50\%).

Table 1 lists the range of physiochemical parameters of $T$. grandis from the literature. UT oil has higher content of stearic acid, linoleic acid, and saturated fatty acids than kernel oil from T. grandis. Therefore, it is possible to enrich sciadonic acid by separating the saturated fatty acids from UT oil. There was no obvious difference between UT oil and other kernel oils of T. grandis $(p<0.05)$ for other physicochemical properties and fatty acid composition. Kernel oil from Torreya species contained at least $1500 \mathrm{ppm}(1500 \mathrm{mg} / \mathrm{kg})$ of tocopherols, which is higher than common soybean oil/rapeseed oil (usually 100-500 ppm). 
Table 1. Properties and fatty acid (content higher than 1\%) composition of different Torreya kernel oils.

\begin{tabular}{|c|c|c|c|}
\hline & $\begin{array}{l}\text { T. fragesii Oil } \\
\text { (UT Oil) }\end{array}$ & $\begin{array}{c}\text { Fractionated } \\
\text { T. fragesii Oil (FT Oil) }\end{array}$ & T. grandis Oil \\
\hline Color (Lovibond 1.0 inch) & $\mathrm{Y} 30+\mathrm{R} 1$ & $\mathrm{Y} 30+\mathrm{R} 0.5$ & - \\
\hline Viscority $20^{\circ} \mathrm{C}, \mathrm{mPa} . \mathrm{s}$ & $55-90$ & $60-90$ & - \\
\hline Density, $20^{\circ} \mathrm{C}, \mathrm{g} / \mathrm{cm}^{3}$ & $0.920-0.930$ & $0.910-0.930$ & - \\
\hline Acid value $(\mathrm{AV}), \mathrm{mg} \mathrm{KOH} / \mathrm{g}$ & $0.35 \pm 0.01^{\mathrm{a}}$ & $0.33 \pm 0.01^{\mathrm{a}}$ & $0.2-3$ \\
\hline Peroxide value (PV), meq/g & $0.56 \pm 0.05^{\mathrm{a}}$ & $0.49 \pm 0.04^{\mathrm{a}}$ & $0.1-1$ \\
\hline Iodine value (IV), $\mathrm{g} \mathrm{I}_{2} / 100 \mathrm{~g}$ & $145 \pm 1.8^{\mathrm{a}}$ & $161 \pm 2.0^{b}$ & $130-150$ \\
\hline Saponification value, $\mathrm{mg} \mathrm{KOH} / \mathrm{g}$ & $186 \pm 2.3^{\mathrm{a}}$ & $188 \pm 2.6^{\mathrm{a}}$ & $180-200$ \\
\hline Unsaponifiable matter, $\%$ & $0.82 \pm 0.05^{\mathrm{a}}$ & $0.76 \pm 0.05^{\mathrm{a}}$ & - \\
\hline Wax, \% & $2.12 \pm 0.25^{\mathrm{a}}$ & $0.05 \pm 0.00^{b}$ & - \\
\hline C16:0, $\%$ by GC, same as below & $9.68 \pm 0.35^{\mathrm{a}}$ & $2.62 \pm 0.25^{b}$ & $7-10$ \\
\hline $\mathrm{C} 18: 0$ & $5.32 \pm 0.23^{a}$ & $3.21 \pm 0.21^{b}$ & $2-4$ \\
\hline C18:1 & $29.36 \pm 0.7^{\mathrm{a}}$ & $20.62 \pm 0.8^{b}$ & $17-33$ \\
\hline $\mathrm{C} 18: 2$ & $39.95 \pm 0.3^{a}$ & $50.68 \pm 0.2^{b}$ & $40-47$ \\
\hline $\mathrm{C} 18: 39 \mathrm{c} 12 \mathrm{c} 15 \mathrm{c}$ & $1.65 \pm 0.10^{\mathrm{a}}$ & $2.58 \pm 0.31^{b}$ & $0.4-1$ \\
\hline $\mathrm{C} 20: 2$ 11c $14 \mathrm{c}$ & $1.98 \pm 0.14^{\mathrm{a}}$ & $2.35 \pm 0.16^{\mathrm{a}}$ & $2-4$ \\
\hline $\mathrm{C} 20: 3$ 5 c 1c $14 \mathrm{c}$ & $11.23 \pm 0.43^{\mathrm{a}}$ & $25.23 \pm 0.45^{b}$ & $9-18$ \\
\hline SFA ${ }^{* *}$ & $15.00 \pm 0.51^{\mathrm{a}}$ & $5.83 \pm 0.48^{b}$ & $10-12$ \\
\hline MUFA ${ }^{* *}$ & $29.36 \pm 1.0^{\mathrm{a}}$ & $23.62 \pm 1.2^{b}$ & $19-35$ \\
\hline PUFA ${ }^{* *}$ & $56.64 \pm 1.5^{\mathrm{a}}$ & $77.76 \pm 1.4^{\mathrm{b}}$ & $53-67$ \\
\hline $\mathrm{UFA}^{* *}$ & $85.00 \pm 1.9^{\mathrm{a}}$ & $94.17 \pm 1.3^{b}$ & $87-89$ \\
\hline Total tocopherols, $\mathrm{mg} / \mathrm{Kg}$ & $1830 \pm 25^{\mathrm{a}}$ & $2020 \pm 32^{b}$ & $1400-2300$ \\
\hline Total polyphenols, $\mathrm{mg} \mathrm{GAE}^{* *} / \mathrm{kg}$ & $5.6 \pm 0.4^{\mathrm{a}}$ & $2.3 \pm 0.3^{b}$ & $3.7-31.1$ \\
\hline Squalene, $\mathrm{mg} / \mathrm{kg}$ & $15.6 \pm 0.05^{\mathrm{a}}$ & $16.2 \pm 0.06^{\mathrm{a}}$ & $16-35$ \\
\hline Total phytosterols, $\mathrm{mg} / \mathrm{kg}$ & $2020 \pm 80^{\mathrm{a}}$ & $1980 \pm 75^{\mathrm{a}}$ & $1200-2200$ \\
\hline
\end{tabular}

* Values in the same row with different superscript letters are significant difference at $p<0.05$. ${ }^{* *}$ SFA:saturated fatty acid; MUFA: monounsaturated fatty acid; PUFA:polyunsaturated fatty acid; UFA:unsaturated fatty acid; GAE:gallic acid equivalent.

\subsection{Dewaxing and Fractionation}

UT oil contains about $2 \%$ wax (Table 2). After dewaxing (WP), the wax content was reduced to $0.45 \%$, with a $95-98 \%$ yield of dewaxing oil. The sciadonic acid content, melting range, and SFC content did not change during dewaxing $(p<0.05$; Table 2). The DSC curve (Supplementary Figure S1) showed two main exothermic processes at about $15-20^{\circ} \mathrm{C}$ and $0-5{ }^{\circ} \mathrm{C}$, indicating that two groups of solid triglycerides can co-crystallize from oil [19]. Thus, the fractionation included a one-step dewaxing and a two-stage cooling process. The one-stageFP1 (from $30^{\circ} \mathrm{C}$ to $5^{\circ} \mathrm{C}$, cooling rate $0.5^{\circ} \mathrm{C} / \mathrm{h}$ ) and two-stageFP3 (rate $1{ }^{\circ} \mathrm{C} / \mathrm{h}, 30-15^{\circ} \mathrm{C} ; 0.5^{\circ} \mathrm{C} / \mathrm{h}, 15-5{ }^{\circ} \mathrm{C}$ ) showed similar results in yield $(75-76 \%$ ) and sciadonic acid content $(25 \%)$ in the liquid fraction; one-stageFP2 $\left(1{ }^{\circ} \mathrm{C} / \mathrm{h}\right)$ decreased the sciadonic acid content $(15 \%)$ in the liquid fraction. The change of stirring rate in FP4 decreased the sciadonic acid content. The liquid fraction ofFP3also showed a lower melting range than that of FP1; the lower melting point can keep the oil transparent in cold weather and is helpful in commercial applications. Based on comprehensive consideration, the two-stageFP3 process saves one-third of the cooling time (as well the energy consumption) over the one-stage cooling process. Therefore, FP3 is a suitable procedure in this study.

As a result, the sciadonic acid content increased from $11 \%$ to $25 \%$; the yield of low-melting-point fraction (FT oil) reached 75\%. Compared with UT oil (Table 1), FT oil had higher UFA, PUFA, and MUFA content, while the SFA content decreased from 15\% (UT oil) to about $6 \%$ (FT oil). For other physicochemical properties, the increased unsaturated number (UFA content) resulted in a larger IV value in FT oil than that in UT oil. There was no significant difference in AV, PV, and saponification value before and after fractionation. Fractionation did not change the content of unsaponifiable matter, which often contains phytochemicals. 
Table 2. The properties of kernel oil after different dewaxing process (WP) and fractionation process (FP).

\begin{tabular}{|c|c|c|c|c|c|}
\hline $\begin{array}{c}\text { Dewaxing/Fractionation } \\
\text { Condition }\end{array}$ & $\begin{array}{l}\text { Yield of Liquid } \\
\text { Fraction } \%\end{array}$ & $\begin{array}{c}\text { Sciadonic Acid } \\
\%\end{array}$ & $\begin{array}{l}\text { Melting Range } \\
\text { (Liquid } \\
\text { Fraction) }\end{array}$ & $\begin{array}{l}\text { Solid Fat Content } \\
\left(25^{\circ} \mathrm{C} \text {, Liquid }\right. \\
\text { Fraction) }\end{array}$ & Wax\% \\
\hline $\begin{array}{l}\text { UT oil, original } \\
\text { WP }\end{array}$ & - & $11.2 \pm 0.8^{a}$ & $13.5^{\mathrm{d}}-16.8^{\mathrm{d}}$ & $10.9 \pm 1.3^{c}$ & $2.12 \pm 0.25^{\mathrm{e}}$ \\
\hline $\begin{array}{c}2{ }^{\circ} \mathrm{C} / \mathrm{h}\left(40-25^{\circ} \mathrm{C}\right), \\
\text { filtration } \\
\text { FP1 }\end{array}$ & $96.8 \pm 1.6^{d}$ & $11.5 \pm 1.3^{a}$ & $12.3^{\mathrm{d}}-15.6^{\mathrm{d}}$ & $10.5 \pm 1.6^{c}$ & $0.45 \pm 0.09^{d}$ \\
\hline $\begin{array}{c}0.5^{\circ} \mathrm{C} / \mathrm{h},\left(30-5{ }^{\circ} \mathrm{C}\right) \\
2 \mathrm{rpm} \\
\mathbf{F P 2}\end{array}$ & $76.6 \pm 1.3^{a}$ & $19.7 \pm 0.8^{d}$ & $4.3^{\mathrm{b}}-7.8^{\mathrm{b}}$ & $2.1 \pm 0.8^{a}$ & $0.06 \pm 0.00^{\mathrm{a}}$ \\
\hline $\begin{array}{c}1^{\circ} \mathrm{C} / \mathrm{h},\left(30-5^{\circ} \mathrm{C}\right) \\
2 \text { rpm } \\
\text { FP } 3 \text { (FT oil) }\end{array}$ & $80.7 \pm 1.8^{b}$ & $15.3 \pm 0.9^{c}$ & $4.6^{b}-8.3^{b}$ & $2.6 \pm 0.6^{b}$ & $0.12 \pm 0.02^{b}$ \\
\hline $\begin{array}{c}1^{\circ} \mathrm{C} / \mathrm{h},\left(30-15^{\circ} \mathrm{C}\right) \\
0.5^{\circ} \mathrm{C} / \mathrm{h},\left(15-5^{\circ} \mathrm{C}\right) \\
2 \mathrm{rpm}\end{array}$ & $75.2 \pm 1.7^{\mathrm{a}}$ & $25.2 \pm 0.9^{d}$ & $3.2^{\mathrm{a}}-5.6^{\mathrm{a}}$ & $1.9 \pm 0.8^{a}$ & $0.05 \pm 0.00^{\mathrm{a}}$ \\
\hline $\begin{array}{c}\text { FP4 } \\
1{ }^{\circ} \mathrm{C} / \mathrm{h},\left(30-15^{\circ} \mathrm{C}\right), \\
0.5^{\circ} \mathrm{C} / \mathrm{h},\left(15-5^{\circ} \mathrm{C}\right), \\
4 \mathrm{rpm}\end{array}$ & $88.6 \pm 2.3^{c}$ & $13.9 \pm 1.5^{\mathrm{b}}$ & $5.5^{c}-9.2^{c}$ & $2.5 \pm 0.3^{b}$ & $0.18 \pm 0.02^{c}$ \\
\hline
\end{tabular}

By comparison, stearidonic acid, a functional lipid, was concentrated to $29 \%$ in Echium seed oil by fractionation with urea encapsulation [20]; oil with high sciadonic acid content (60\%) was isolated by combining enzymatic esterification and urea encapsulation from kernel oil of $T$. grandis [3]. The use of urea and enzymes increases production costs, and urea may cause harmful residues.

\subsection{Stability of Fractionated Oil}

As shown in Figure 2, the AV of the two oil samples changed slowly in 42 days $(p<0.05)$ and the difference between FT oil and UT oil was not significant $(p<0.05)$, indicating that the increased sciadonic acid content did not affect the AV.

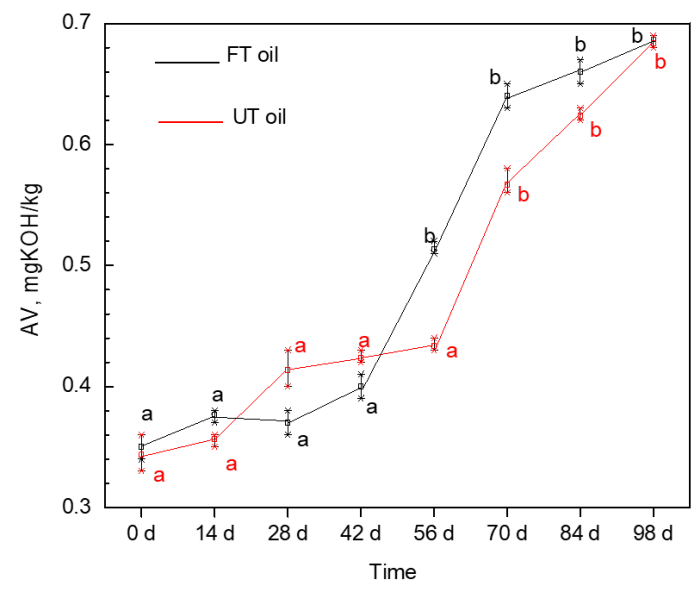

(a)

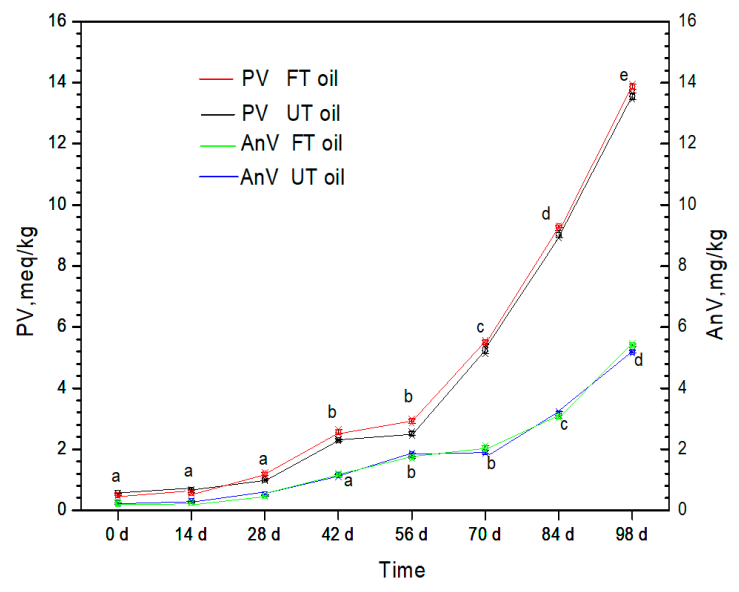

(b)

Figure 2. $\mathrm{AV}(\mathbf{a}), \mathrm{PV}$ and $\mathrm{AnV}(\mathbf{b})$ of UT oil and FT oil in the long-term storage test.

After a 3 month (98 d) test, the AV of FT oil and UT oil was about $0.7 \mathrm{mg} \mathrm{KOH} / \mathrm{kg}$. The moisture absorbed by oil samples from the air is a possible reason for increased AV. PV and AnV did not change significantly within $28 \mathrm{~d}(p<0.05)$, and then increased rapidly after $56 \mathrm{~d}$ of storage. There was no difference in PV and AnV between FT oil and UT oil in $98 \mathrm{~d}(p<0.05)$. The storage test under natural conditions can support potential commercial applications, such as best flavor period after opening, package details, and addition of antioxidants. 
The Schaal test can reflect the oxidant sensitivity of PUFA under heating conditions. In $24 \mathrm{~h}$, there was no significant difference in the change of Av and PV; no difference was found between FT oil and UT oil ( $p<0.05$; Figure 3). PV continually increased from about $1.0 \mathrm{mEq} / \mathrm{g}$ to $20.0 \mathrm{mEq} / \mathrm{g}$ over $72 \mathrm{~h}$ of heating. There was no difference in PV between FT and UT oil during the testing period $(p<0.05)$. The long-term and Schaal tests indicated that the stability of FT oil does not decrease as its PUFA content increases. This is partly attributed to the increased tocopherols content in FT oil (from 1830 to $2020 \mathrm{mg} / \mathrm{kg})$.

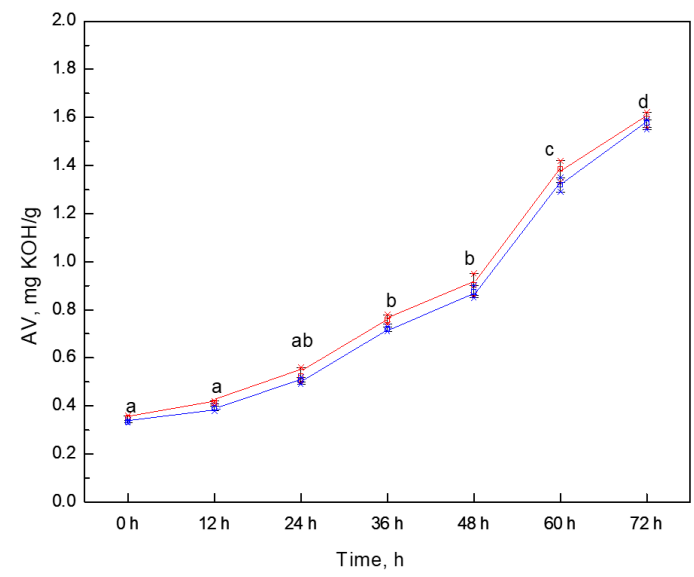

(a)

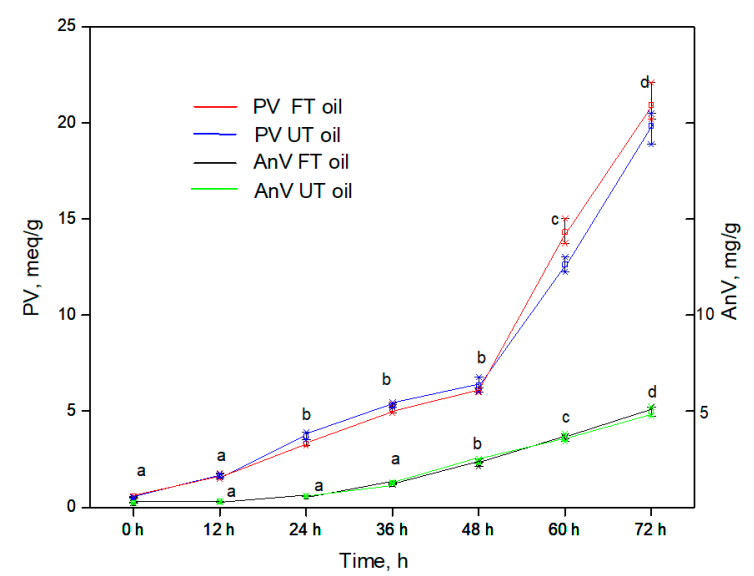

(b)

Figure 3. (a), PV and AnV (b) of UT oil and FT oil in a Schaal accelerated test. * The same lowercase letters means the no significant difference between values of different days in the same curve $(p<0.05)$. ** No significant difference between the curves of AV, PV and AnV for FT oil and UT oil $(p<0.05)$.

*** Data are presented as mean $\pm \mathrm{SD}, p<0.05$.

\subsection{Radical Scavenging Test}

\subsubsection{DPPH Scavenging Efficiency}

The chemical mechanism of the free radical scavenging test usually includes single electron transfer (SET, such as DPPH) and hydrogen atom transfer (HAT, typical of ORAC) [21]. Results of the DPPH assay showed that the radical scavenging ability of FT oil was similar to that of UT oil $(p<0.05)$ at all concentrations. The scavenging efficiency was about $65 \%$ when the concentration of FT oil was higher than $8 \mathrm{mg} / \mathrm{mL}$. As shown in Table 3, FT oil showed similar scavenging activity $(502 \pm 18 \mu \mathrm{mol} \mathrm{TE} / 100 \mathrm{~g})$ to UT oil $(485 \pm 15 \mu \mathrm{mol} \mathrm{TE} / 100 \mathrm{~g})$, which is consistent with their removal efficiency. The DPPH radical-scavenging activity and polyphenols content were highly correlated, and the polyphenols content was similar in FT and UT oil. The increasing content of tocopherols (61.6 $\mu \mathrm{g}$ TE/mL, about $24 \mu \mathrm{mol} \mathrm{TE} / 100 \mathrm{~g}$ [22]) cannot influence the DPPH activity between FT oil and UT oil.BothUT and FT oil showed equal DPPH scavenging ability to the reported Torreya oils (between 422 and $509 \mu \mathrm{mol} \mathrm{TE} / 100 \mathrm{~g})[11,12,14]$. The $\mathrm{IC}_{50}$ of FT and UT oil was about $6.0 \mu \mathrm{g} / \mathrm{mL}$, lower than that of the chemically synthesized BHT (about $1.75 \mu \mathrm{g} / \mathrm{mL}$ ) but stronger than the EGCG (90 $\mu \mathrm{g} / \mathrm{ML}$ [23]). This indicates that the DPPH scavenging activity of FT oil was limited. 
Table 3. Scavenging ability and LOX-5 inhibition efficiency of different Torreya kernel oils.

\begin{tabular}{|c|c|c|c|c|c|c|}
\hline & UT Oil & FT Oil & EGCG $^{* *}$ & $\begin{array}{l}\text { T. grandis } \\
\text { Oil }\end{array}$ & BHT & NDGA $^{* *}$ \\
\hline $\begin{array}{c}\text { ORAC } \\
\mu \mathrm{mol} \mathrm{TE} / 100 \mathrm{~g}\end{array}$ & $445 \pm 12^{a}$ & $458 \pm 10^{a}$ & $8000 \pm 124$ & $260-435$ & - & - \\
\hline $\begin{array}{c}\text { DPPH } \\
\mu \mathrm{mol} \mathrm{TE} / 100 \mathrm{~g}\end{array}$ & $485 \pm 15^{a}$ & $502 \pm 18^{a}$ & - & $422-509$ & - & - \\
\hline $\begin{array}{l}\mathrm{DPPH} \mathrm{IC}_{50} \\
\mu \mathrm{g} / \mathrm{ml}\end{array}$ & $6.12 \pm 0.05^{\mathrm{a}}$ & $5.90 \pm 0.12^{a}$ & 90 & - & $1.75 \pm 0.03$ & - \\
\hline $\begin{array}{c}\text { LOX-5 IE\% } \\
\text { (Concentration of oil) }\end{array}$ & $\begin{array}{c}32.1 \pm 2.3^{\mathrm{a}} \\
(66.7 \mu \mathrm{g} / \mathrm{mL})\end{array}$ & $\begin{array}{l}65.2 \pm 3.1^{\mathrm{b}} \\
(66.7 \mu \mathrm{g} / \mathrm{mL})\end{array}$ & - & - & - & $\begin{array}{c}100 \pm 0 \\
(10 \mu \mathrm{g} / \mathrm{mL})\end{array}$ \\
\hline $\begin{array}{l}\text { LOX-5 IC } 50 \\
\mu \mathrm{g} / \mathrm{ml}\end{array}$ & - & $47.8 \pm 1.3$ & - & - & - & $2.95 \pm 0.21$ \\
\hline
\end{tabular}

* Values in the same row with different superscript letters are significant difference at $p<0.05 .{ }^{* *}$ EGCG: epigallocatechin gallate; BHT:2,6-di-tert-butyl-4-methyl phenol; NDGA: nordihydro-guaiaretic acid.

\subsubsection{ORAC Capacity}

As shown in Table 3, the methanol extract of FT oil had a higher ORAC value (468 $\mu \mathrm{mol}$ TE/ $100 \mathrm{~g})$ than the UT oil $(445 \mu \mathrm{mol} \mathrm{TE} / 100 \mathrm{~g})(p<0.05)$, but their values are far below water-soluble epigallocatechin gallate(EGCG, about $8000 \mu \mathrm{mol} \mathrm{TE} / 100 \mathrm{~g}$ ).The reported ORAC values of $T$. grandis kernel oil varied from 260 to $435 \mu \mathrm{mol} \mathrm{TE} / 100 \mathrm{~g}$ [12,14].The tocopherols, phytosterols, and polyphenols were highly indicative of the strong ORAC value of plant oil. In general, tocopherols usually accumulate in the liquid phase (FT oil) in fractionation. The ORAC of tocopherols varies from 1200 to $2000 \mu \mathrm{mol} / \mathrm{g}$ [24], so the increased tocopherols content (about $0.02 \mathrm{~g}$ increment in FT oil, 24-40 $\mu \mathrm{mol}$ TE/100g FT oil) contributed to the stronger ORAC of FT oil. Meanwhile, the stability of FT oil did not change as its PUFA content increased, due to increased tocopherols.

\subsection{Anti-inflammatory Effect}

\subsubsection{PDE Inhibition}

The inhibition efficiency toward PDE- 5 increased to over $80 \%$ with increased FT oil concentration to $133.7 \mu \mathrm{g} / \mathrm{mL}$; a higher concentration of FT oil only increased efficiency to about $85 \%$ (Figure 4). FT oil with $25 \%$ sciadonic acid had stronger inhibition capacity than UT oil with $11 \%$ sciadonic acid UT oil $(133.7 \mu \mathrm{g} / \mathrm{mL})$ showed only about $40 \%$ inhibition efficiency, suggesting that the enrichment of sciadonic acid effectively enhances PDE- 5 inhibition ability. The possible inhibition activity of tocopherols on PDE- 5 can be excluded by the reference test, by which UT oil with $2000 \mathrm{mg} / \mathrm{kg}$ tocopherols showed only about 35\% inhibition efficiency. We used EDTA and L-cysteine as positive and negative references, respectively, to evaluate PDE-5 inhibition activity. The efficiency between EDTA (about $80 \%$ ) and L-cysteine (about $8 \%$ ) was regarded as effectively anti-inflammatory. The inhibition efficiency of FT oil $(133.7 \mu \mathrm{g} / \mathrm{mL})$ was about $78 \%$, indicating its potential anti-inflammatory value. As reference, the aqueous extract of nutmeg showed over $90 \%$ inhibition efficiency on PDE-5 at $500 \mu \mathrm{g} / \mathrm{mL}$ [25]; in a cell model test, East Indian sandalwood oil showed about 70\% inhibition efficiency on PDEs ata concentration of $0.0001-0.0002 \%$ [26].

\subsubsection{LOX Inhibition}

The inhibition of LOX-5 (Table 3) revealed that FT oil (inhibition efficiency $65.2 \%$, with $25 \%$ sciadonic acid) was twice as effective as UT oil ( $32.1 \%$, with $11 \%$ sciadonic acid). The $10 \%$ increased tocopherols content in FT oil cannot double the LOX-5 inhibition activity, indicating that the inhibition of LOX-5is related to the concentration of sciadonic acid in the kernel oil.The increased FT oil concentration in the test system could not increase the inhibition efficiency clearly, which was similar to the PDE-5 inhibition test. The inhibition efficiency of FT oil was about two-thirds of NGDA (stronger inhibitor of LOX enzymes), showing its potential value in anti-inflammatory applications. For comparison, the oil 
from Psidiumguajava fruits showed an $\mathrm{IC}_{50}$ of about $196 \mu \mathrm{g} / \mathrm{mL}$ on LOX-5 [27], and the essential oil from thyme species only showed $12 \%$ efficiency at $100 \mu \mathrm{g} / \mathrm{mL}$ [28].

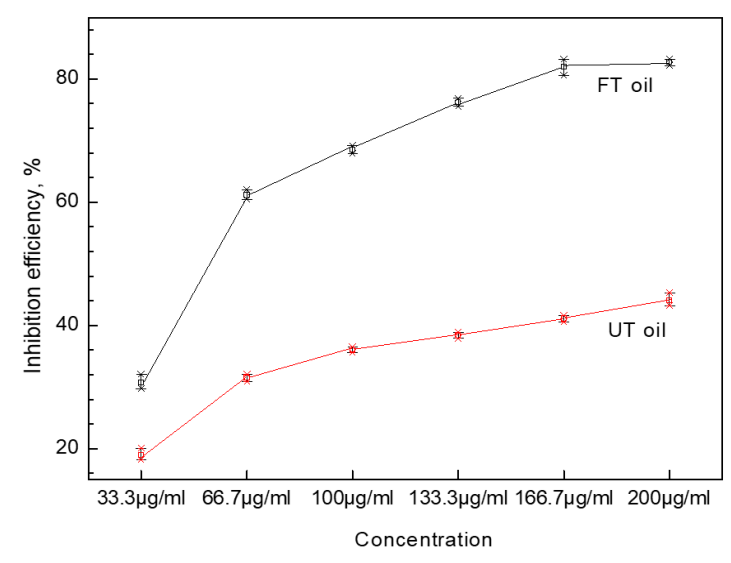

(a)

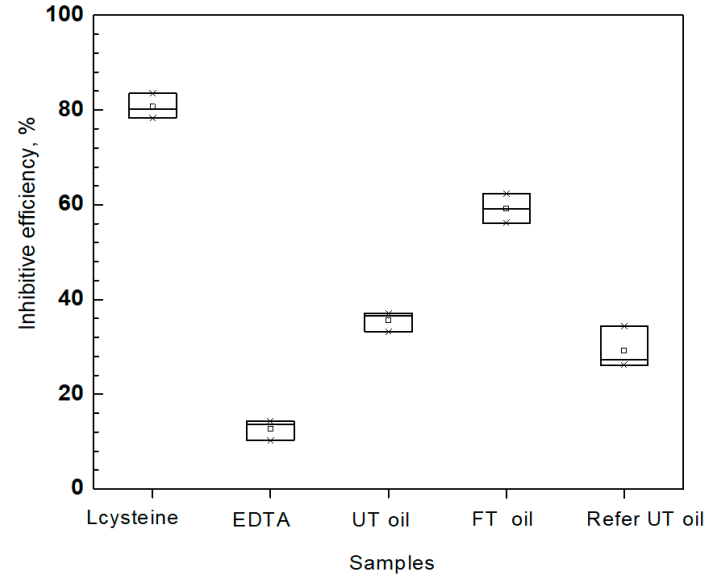

(b)

Figure 4. The inhibition efficiency of PDE-5 by UT oil and FT oil (a) and the comparison test with EDTA and L-cysteine $(\mathbf{b})$, (data are presented as mean $\pm \mathrm{SD}, p<0.05$ ).

\subsubsection{Inhibition of Mouse Ear Edema}

The inhibition of topical edema on mouse ears induced by xylene is shown in Figure 5 . The right ears of mice developed discernible edema after xylene contamination. Treatment with FT oil significantly decreased the weight of edematous ears by $63.1 \%$, which is higher than with UT oil (29.4\%) but lower than the most effective aspirin (72.5\%). UT oil with the same amount of tocopherols as FT oil $(2000 \mathrm{mg} / \mathrm{kg})$ only showed $31.8 \%$ inhibition. This indicated that the increased anti-swelling capacity is independent of the tocopherols content in FT oil. As a comparison, the volatile oil of Houttuyniacordata Thunb. was reported to have $67.6 \%$ inhibition efficiency on xylene-induced ear edema in mice [29], while research on pumpkin seed oil showed about $70 \%$ inhibition of edema induced by $0.02 \mathrm{~mL}$ xylene on each ear [30]. This indicates the practical anti-inflammatory effect of FT oil in commercial applications.

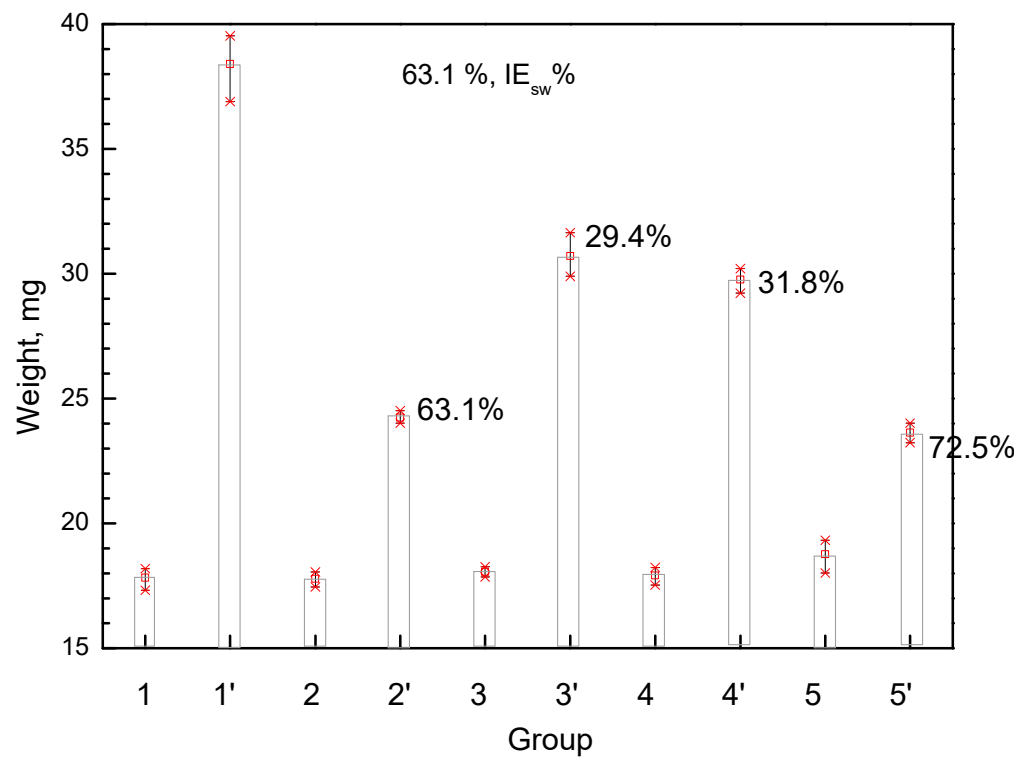

Figure 5. Effect of FT oil and UT oil on xylene induced ear inflammation in mice. ( $\mathrm{n}=15$, Data are presented as mean $\pm \mathrm{SD}, p<0.05 ; 1,2,3,4,5$ right ear, $1^{\prime}, 2^{\prime}, 3^{\prime}, 4^{\prime}, 5^{\prime}$ left ear,.1, $1^{\prime}$ control, 2,2' with FT oil, $3,3^{\prime}$ with UT oil, $4,4^{\prime}$ with reference (UT oil with $2000 \mathrm{mg} / \mathrm{kg}$ tocopherols), 5, $5^{\prime}$ with aspirin). 


\section{Conclusions}

Fractionation can effectively increase the sciadonic acid content in kernel oil of Torreya fargesii from $11 \%$ to $25 \%$. Fractionated kernel oil of Torreya fargesii has similar stability, physicochemical properties, and antioxidant capacity as non-fractionated kernel oil. In anti-inflammatory assays, fractionated kernel oil showed inhibition of PDE-5/LOX-5 enzymes and mouse ear edema better than non-fractionated oils.This study provides an economical method for enriching sciadonic acid from the kernel oil of Torreya fargesii and demonstrates that oil rich in sciadonic acid has enhanced anti-inflammatory capacity.In this respect, further research on the mechanism of anti-inflammatory and other pharmacological effects of sciadonic acid and kernel oil may be of interest.

\section{Materials and Methods}

\subsection{Chemicals}

The mixed standard of fatty acid methyl esters (18916-1AMP), 2,2-diphenyl-1-picrylhydrazyl (DPPH), 2,2'-azobis(2-methylpropionamidine) dihydrochloride (AAPH), ( \pm )-6-hydroxy-2,5,7,8tetra-methylchromane-2-carboxylic acid (Trolox), squalene (442785), $\alpha$-cholestane, disodium (4-nitrophenyl) phosphate (4-NPP), 5-lipoxygenase (L6632), and phosphodiesterase (P4631) were purchased from Sigma-Aldrich (St. Louis, MO, USA). Pure water was produced by a Milli-Q Academic A10 system (Millipore, Burlington, MA, USA). Other reagents (in analytical grade) were purchased from Sinopharm (Shanghai, China).

\subsection{Animals}

Kunming mice (17-22 g) were purchased from HFK Bioscience Technology (Beijing, China). They were placed in plastic boxes at about $25^{\circ} \mathrm{C}$ and fed for 15 days in a laboratory environment before the test. The animal experiments were approved by the Laboratory Animal Ethics Committee of Chongqing University (permit number: 2019121).

\subsection{Preparation of Kernel Oil of T. fargesii}

The seeds of T. fargesii were gathered at Daba Mountain (Chongqing Municipality, China) in October 2018. The kernels were obtained after peeling off arils and subsequently dehulling shells. After desiccating at $30{ }^{\circ} \mathrm{C}$ in vacuum for $48 \mathrm{~h}$ (moisture $3 \%-6 \%$ ), the prepared kernels were crushed to about 5-10 $\mathrm{mm}$ size (using a sieve to control the particle size). Then the crushed kernels were pressed in a screw-type oil expeller (YZY-X 12 P, Kangyuan Sinomech., Beijing, China). The prepared crude oil was centrifuged at $8000 \mathrm{rpm}$ for $15 \mathrm{~min}$. The clear upper oil phase was collected and stored in a refrigerator at $4{ }^{\circ} \mathrm{C}$.

\subsection{Physicochemical Properties of Kernel Oil}

The oil content of the kernels and meal was determined by the American Oil Chemists' Society (AOCS) method Am 2-93. The physicochemical properties of the oil sample, including wax content (Ch 8-02), moisture and volatile matter (Ba 2a-38), acid value (AV, $\mathrm{Cd} 3 \mathrm{~d}$ 63), peroxide value (PV, Cd 8b-90), unsaponifiable matter(Ca 6a-40), iodine value (IV, Tg1a-64), saponification value (SV, Cd 3c-91), fatty acid composition (Ce 1a-13), tocopherols (Ce 8-89), and phytosterols content (Ce 12-16), were measured using the official standardized AOCS methods [31].Viscosity was tested on a DV2T viscometer(Brookfield, Toronto, Canada).

\subsubsection{Total Polyphenols Content}

Using a modified method [11], $1 \mathrm{~g}$ oil (diluted with $7 \mathrm{~mL}$ hexane) was loaded on a $500 \mathrm{mg}$ Sepax Generik Diol column (Sepax Technologies, Newark, DE, USA). The column was successively washed with $6 \mathrm{~mL}$ of $n$-hexane, $2 \mathrm{~mL}$ of ethyl acetate, and $10 \mathrm{~mL}$ of methanol. These eluants were combined 
and $3 \mathrm{~mL}$ was orderly mixed with $0.5 \mathrm{~mL}$ of Folin-Ciocalteu reagent and $1 \mathrm{~mL}$ of sodium carbonate solution (15\%), and then metered to $10 \mathrm{~mL}$ with water. After $2 \mathrm{~h}$ incubation in a dark place, the prepared solution was measured at $760 \mathrm{~nm}$ on a UV 2700 spectrometer (Shimadzu, Kyoto, Japan) using gallic acid as a reference. The result was expressed as gallic acid equivalent (GAE) per kilogram of oil.

\subsubsection{Squalene}

An oil sample $(0.5 \mathrm{~g})$ was saponified with $50 \mathrm{~mL} \mathrm{KOH} /$ ethanol solution $(2 \mathrm{~mol} / \mathrm{L})$ at $85^{\circ} \mathrm{C}$ for $1 \mathrm{~h}$ and then extracted by $25 \mathrm{~mL}$ hexane three times. The hexane extracts were combined and washed with ethanol and dried with anhydrous $\mathrm{Na}_{2} \mathrm{SO}_{4}$. The as-prepared sample was tested on a Shimadzu GC-9A chromatograph equipped with a Stabilwax-DA capillary column using pure squalene as the internal standard; the other details were similar to a previous study [32].

\subsection{Dewaxing and Fractionation}

About $500 \mathrm{~g}$ of oil sample was cooled using the preset cooling program in a cryotrap (DC0506 Shanghai Jingying Co.,Ltd., Shanghai, China). In the dewaxing process, the UT oil was cooled from $40{ }^{\circ} \mathrm{C}$ to $25{ }^{\circ} \mathrm{C}$ at $2{ }^{\circ} \mathrm{C} / \mathrm{h}$ steps without stirring. After the $2 \mathrm{~h}$ settlement at $25^{\circ} \mathrm{C}$, the precipitated wax was filtrated from the oil under cooling conditions. The cooling program referred to the DSC analysis of UT oil and a published document [33]. The fractionation was set as a1-stage or 2-stage crystallization with different cooling and stirring rates. After each cooling process, the oil mixture was kept at the final temperature for $4 \mathrm{~h}$, then the liquid fraction (FT oil) and solid fraction were separated by centrifugation $(10,000 \mathrm{rpm}, 5 \mathrm{~min})$. In the 2 -stage crystallization, the liquid fraction from the first crystallization was used for a further cooling process. The solid fat content (SFC) of fractions was measured by NMR (AOCS Cd 16b-93) on an MQC micro-NMR spectrometer (Oxford, England, UK). The wax and sciadonic acid content, and melting range (AOCS Cc 1-25) were also measured to evaluate the efficiency of fractionation.

\subsection{Stability of Fractionated Oil}

In the 98-day long-term storage test, a $200 \mathrm{~mL}$ oil sample was metered in an opened plastic bottle, which was placed at room temperature with natural light irradiation. Then $5 \mathrm{~mL}$ of oil was pipetted every 14 days to determine its acid value (AV), peroxide value (PV), and anisidine value (AnV). In the Schaal test, a $250 \mathrm{~mL}$ oil sample in a glass flask was heated in an oven at $63( \pm 1)^{\circ} \mathrm{C}$. PV, AV, and $\mathrm{AnV}$ were measured every $8 \mathrm{~h}$, and the overall heating time was $72 \mathrm{~h}$.

\subsection{DPPH and ORAC assays}

\subsubsection{DPPH}

DPPH radical scavenging ability of the oil samples was assessed according to the reported method [34]. Typically, different amounts of test oil solution $(100 \mathrm{mg} / \mathrm{mL}$ in ethyl acetate) and $2 \mathrm{~mL}$ of $0.1 \mathrm{mmol} / \mathrm{L}$ DPPH reagent were diluted with ethyl acetate to volume. After incubation in a dark place for $2 \mathrm{~h}$ at room temperature, the absorbance of the reactant system was measured at $515 \mathrm{~nm}$ on a Shimadzu UV 2700 spectrophotometer with a $1 \mathrm{~cm}$ quartz cuvette. Trolox solution (in ethyl acetate) was used to prepare the work curve. 2,6-di-tert-Butyl-4-methyl phenol(BHT) and ethanol were the positive control and reagent blank, respectively. The scavenging efficiency (E\%) of DPPH radicals was calculated using the following equation:

$$
E \%=\left(1-\frac{A_{1}}{A_{0}}\right) \times 100 \%
$$

where $A_{1}$ and $A_{0}$ are the absorbance of the reactant solution and the reagent blank, respectively. Antioxidant activity was also expressed as antioxidant equivalent to Trolox (an analogue of vitamin E, $\mu \mathrm{mol} \mathrm{TE} / 100 \mathrm{~g}$ of oil). 


\subsubsection{ORAC}

The method was modified from published research [35]. The oil sample $(50 \mathrm{~mL})$ was first extracted with an equal volume of $80 \%$ methanol for $15 \mathrm{~min}$ in an ultrasonic bath, then the methanol layer was collected by centrifugation $(8000 \mathrm{rpm}, 10 \mathrm{~min})$. For a typical measurement, FL reagent $(150 \mu \mathrm{L}$, $0.08 \mu \mathrm{mol} / \mathrm{L}$ ) in phosphate-buffered saline (PBS) buffer $(\mathrm{pH}=7.4)$ and $20 \mu \mathrm{L}$ of methanol extract of oil sample was mixed on a 96-well plate. The mixture was shaken for $3 \mathrm{~min}$ and incubated at $37^{\circ} \mathrm{C}$ in the dark for $15 \mathrm{~min}$, and then the AAPH solution $(25 \mu \mathrm{L}, 150 \mathrm{mM})$ was added to initiate the reaction. The decay of fluorescent emission was measured at $37^{\circ} \mathrm{C}$ every 3 min at $525 \mathrm{~nm}$ (excitation at $485 \mathrm{~nm}$ ) using a Multiskan MK3 reader (Thermo, Waltham, MA, USA). ORAC of test samples was determined by using Trolox as a standard; the integral areas of fluorescence peaks from samples and Trolox were calculated by the software. The result was expressed as $\mu \mathrm{mol}$ Trolox equivalent/g ( $\mu \mathrm{mol} \mathrm{TE} / \mathrm{g}$ ).

\subsection{Anti-inflammatory Assay}

In a typical PDE inhibitory test [36], the 4-NPP substrate (10 $\mu \mathrm{L}, 0.33 \mathrm{mM}$ in PBS), oil sample $(5 \mathrm{mg} / \mathrm{mL}$ in acetone), and $0.35 \mu \mathrm{U}$ PDE (in PBS buffer) were mixed in the wells of a 96-well plate. After incubation at $37^{\circ} \mathrm{C}$ for $45 \mathrm{~min}$, the optical density (OD) value of reactant was measured at $405 \mathrm{~nm}$ on a Thermo Multiskan MK3 reader, and the inhibition efficiency was calculated from the OD value using the following equation:

$$
I E \%=\left(\frac{O D_{\mathrm{bl}}-O D_{\mathrm{s}}}{O D_{\mathrm{s}}}\right) \times 100 \%
$$

where the subscripts s and bl indicate sample (UT and FT oil) and reagent blank, respectively. The strong inhibitor EDTA and weak inhibitor L-cysteine were used as positive comparison.

The LOX inhibitory test was modified from a previous study [37]. In a typical measurement, $40 \mu \mathrm{L}$ LOX-5 solution (50 times dilution in water) was incubated at $30^{\circ} \mathrm{C}$ for $45 \mathrm{~min}$ with a $20 \mu \mathrm{L}$ oil sample $\left(200 \mu \mathrm{g} / \mathrm{mL}\right.$ in acetonitrile). Then $50 \mu \mathrm{L}$ linoleic acid was added, and after incubation for $3 \mathrm{~min}$ at $30^{\circ} \mathrm{C}$, $500 \mu \mathrm{L}$ ethanol and $500 \mu \mathrm{L}$ water were added to terminate the reaction. Then the reactant was measured at $234 \mathrm{~nm}$ on a Thermo Multiskan MK3 reader, and the OD value was used to calculate the inhibition efficiency (IE\%) by Equation (2). Here, the subscripts $\mathrm{s}$ and bl indicate sample and reagent blank, respectively. Nordihydroguaiatic acid (NGDA, IE $\%=100 \%, \mathrm{IC}_{50}=2.95 \pm 0.21 \mu \mathrm{g} / \mathrm{mL}$ ) [28] was used as a positive control to calculate the IE\% of oil samples. The formation of hydroperoxide conjugated dienes gave strong absorption at $234 \mathrm{~nm}\left(\varepsilon>25,000 \mathrm{M}^{-1} \cdot \mathrm{cm}^{-1}\right)$. The interference of sciadonic acid (polyene structure, $\varepsilon_{220-260 \mathrm{~nm}}<1000 \mathrm{M}^{-1} \mathrm{~cm}^{-1}$ ) on the test results can be omitted.

In an anti-edema test, 75 mice ( 37 males and 38 females) were divided randomly into five groups ( $\mathrm{n}=15$ : control, FT oil, UT oil, reference, and positive groups). UT oil with the same tocopherols content as FT oil was the reference, and aspirin (total dosage $0.2 \mathrm{mg} / \mathrm{cm}^{2}$ on ear) was the positive group. Inflammation was induced by dosing with $0.05 \mathrm{~mL}$ of xylene on both sides of the ears (right ear as control). After $30 \mathrm{~min}$ of xylene contamination, oil samples $(0.05 \mathrm{~mL})$ and aspirin solution were applied to the left and right ears at $1 \mathrm{~h}$ intervals over $12 \mathrm{~h}$. The mice were killed, and an $8 \mathrm{~mm}$ diameter patch was punched into the left (weight, $W_{1}$ ) and right (weight, $W_{\mathrm{r}}$ ) ears; the weight margin of the 2 patches was calculated as the swelling inhibition degree [38] $\left(\mathrm{IE}_{\mathrm{sw}} \%\right)$ :

$$
I E_{\mathrm{sw}} \%=\left(\frac{W_{1}-W_{\mathrm{r}}}{W_{\mathrm{r}}}\right) \times 100 \%
$$

\subsection{Statistical Analysis}

All oil samples were tested in triplicate and in a random order. To indicate the difference of data within a group, multiple comparison was performed by one-way ANOVA and, successively, Tukey's test using SPSS Statistics 15.0 (SPSS Inc., Chicago, IL, USA) at a P-value less than or equal to 0.05 . Student's $t$ test was used to compare the statistical significance between the original UT oil and fractionated FT oil. 
Supplementary Materials: The following are available online, Figure S1: DSC cooling profile $\left(-3^{\circ} \mathrm{C} / \mathrm{min}\right)$ of UT oil (exothermal peaks are shown upwards).

Author Contributions: Conceptualization, X.Z.; methodology, M.Q. and B.J.; validation, X.Z., J.W. and B.J.; formal analysis, H.Y. and Y.Z.; investigation, X.Z., J.S., H.Y. and Y.Z.; resources, J.W.; data curation, X.Z. and Y.Z.; writing original draft, X.Z.; supervision, J.S.; project administration, J.S.; funding acquisition, J.S. and X.Z.

Funding: Financial support was provided by the National Natural Science Foundation of China (31470568).

Conflicts of Interest: The authors declare that there is no conflict of interests regarding the publication of this article

\section{References}

1. Wolff, R.L.; Bayard, C.C. Fatty acid composition of some pine seed oils. J. Am. Oil. Chem. Soc. 1995, 72, 1043-1046. [CrossRef]

2. Pedrono, F.; Boulier-Monthean, N.; Biossel, F.; Ossemond, J.; Devehat, F.L. The Hypo triglyceridemic Effect of Sciadonic Acid is Mediated by the Inhibition of $\Delta_{9}$-Desaturase Expression and Activity. Mol. Nutr. Food Res. 2017, 62, 1-11.

3. Gambelli, L.; Schmid, U. Use of a polyunsaturated fatty acid compound. US Patent No. 12/306,292, 13 August 2009.

4. Destaillats, F.; Cruz-Hernandez, C.; Dionisi, F.; Masserey-Elmelegy, I.; Manuel-Oliveira, M.; Moulin, J. Sn-1(3) Monoacylglycerides and lipid absorption. US Patent US9000039B2, 7 April 2015.

5. Endo, Y.; Tsunokake, K.; Ikeda, I. Effects of non-methylene-interrupted polyunsaturated fatty acid, sciadonic (all-cis-5,11,14-eicosatrienoic acid) on lipid metabolism in rats. Biosci. Biotech. Biochem. 2009, 73, 577-581. [CrossRef] [PubMed]

6. Huang, W.C.; Tsai, P.J.; Huang, Y.L.; Chen, S.N.; Chuang, L.T. PGE2 production is suppressed by chemically-synthesized $\Delta_{7}$-eicosatrienoic acid in macrophages through the competitive inhibition of COX-2. Food Chem. Toxicol. 2014, 66, 122-133. [CrossRef] [PubMed]

7. Chen, S.J.; Chuang, L.T.; Liao, J.S.; Huang, W.C.; Lin, H.H. Phospholipid Incorporation of Non-Methylene-Interrupted Fatty Acids (NMIFA) in Murine Microglial BV-2 Cells Reduces Pro-Inflammatory Mediator Production. Inflammation 2015, 38, 2133-2145. [CrossRef] [PubMed]

8. Wolff, R.L.; Pedronoa, F.; Marpeau, A.M.; Christie, W.W.; Gunstone, F.D. The seed fatty acid composition and the distribution of $\Delta_{5}$-olefinic acids in the triacylglycerols of some taxaceae (Taxus and Torreya). J. Am. Oil. Chem. Soc. 1998, 75, 1637-1641. [CrossRef]

9. Wolff, R.L.; Pedronoa, F.; Marpeau, A.M.; Gunstone, F.D. The seed fatty acid composition and the distribution of $\Delta_{5}$-olefinic acids in the triacylglycerols of some taxares (Cephalotaxus and Podocarpus). J. Am. Oil. Chem. Soc. 1999, 76, 469-473. [CrossRef]

10. He, Z.Y.; Zhu, H.D.; Li, W.L.; Zeng, M.M.; Wu, S.F.; Chen, S.W.; Qin, F.; Chen, J. Chemical components of cold pressed kernel oils from different Torreya grandis cultivars. Food Chem. 2016, 209, 196-202. [CrossRef]

11. Shi, L.K.; Mao, J.H.; Zheng, L.; Zhao, C.W.; Jin, Q.Z.; Wang, X.G. Chemical characterization and free radical scavenging capacity of oils obtained from Torreya grandis Fort. ex. Lindl. and Torreya grandis Fort. var. Merrillii: A comparative study using chemometrics. Ind. Crop. Prod. 2018, 115, 250-260. [CrossRef]

12. Shi, L.K.; Zheng, L.; Mao, J.H.; Zhao, C.W.; Huang, J.H.; Liu, R.J.; Chang, M.; Jin, Q.Z.; Wang, X.G. Effects of the variety and oil extraction method on the quality, fatty acid composition and antioxidant capacity of Torreya grandis kernel oils. LWT Food Sci. 2018, 91, 398-405. [CrossRef]

13. Xu, C.; Shao, X.F.; Li, H.S. Supercritical carbon dioxide extraction, fatty acid composition, oxidative stability, and antioxidant effect of Torreya grandis seed oil. J. Am. Oil. Chem. Soc. 2014, 91, 817-825.

14. Ni, L.; Shi, W.Y. Composition and free radical scavenging activity of kernel oil from Torreya grandis, Caryacathayensis, and Myricarubra. Iran. J. Pharma. Res. Ijpr. 2014, 13, 221-226.

15. Yu, Y.J.; Ni, S.; Wu, F.; Sang, G.W. Chemical Composition and Antioxidant Activity of Essential Oil from Torreya grandis cv. merrillii Arils. J. Essent. OilBear. Pl. 2016, 19, 1170-1180. [CrossRef]

16. Jang, B.; Zhou, X.R.; Shang, J.; Wang, J.H.; Song, H.; Qin, M.Y.; Liu, X.N.; Wang, Q. Population structure and dynamics of Torreya fargesii Franch, a plant endemic to China. Acta. Ecol. Sin. 2018, 38, 1016-1027. (In Chinese). 
17. Shang, J.; Wang, J.H.; Zhou, X.R.; Jiang, B.; Qin, M.Y. Ultrasound Extraction of Total Flavonoids from Torreya Fargesii Franch. and Its Antioxidant Activity Based on Response Surface Methodology (RSM). Fresen. Envir. Bull. 2017, 26, 611-617.

18. Zhou, X.R.; Shang, J.; Wang, J.; Jiang, B.; Wang, Q. Antioxidant activity of extracts from the aril of Torreya fargesii Franch. And its protection on the oxidation of DHA algal oil. CyTA-J. Food 2018, 16, 381-389. [CrossRef]

19. Li, X.; Cao, J.; Bai, X.P.; Zhang, F.F. Chemical composition and thermal properties of tilapia oil extracted by different methods. Inter. J. Food Prop. 2018, 21, 1575-1585. [CrossRef]

20. Vazquez, L.; Ortego, E.; Corzo-Martínez, M.; Reglero, G.; Torres, C.F. Stearidonic Acid Concentration by Urea Complexation from Echium Oil. J. Oleo. Sci. 2018, 67, 1091-1099. [CrossRef]

21. Cao, G.; Alessio, H.M.; Cutler, R.G. Oxygen-radical absorbance capacity assay for antioxidants. Free Radical. Bio. Med. 1993, 14, 303-311. [CrossRef]

22. Shimamura, T.; Sumikura, Y.; Yamazaki, T.; Tada, A.; Kashiwagi, T.; Ishikawa, H.; Matsui, T.; Sugimoto, N.; Akiyama, H.; Ukeda, H. Applicability of the DPPH Assay for Evaluating the Antioxidant Capacity of Food Additives Inter-laboratory Evaluation Study. Anal. Sci. 2014, 30, 717-721. [CrossRef]

23. Nikoo, M.; Regenstein, J.M.; Gavlighi, H.A. Antioxidant and antimicrobial activities of (-)-epigallocatechin3-gallate (EGCG) and its potential to preserve the quality and safety of foods. Compr. Rev. Food Sci. F. 2018, 17, 732-753. [CrossRef]

24. Naguib, Y.; Hari, S.P.; Passwater, R., Jr.; Huang, D. Antioxidant activities of natural vitamin E formulations. J. Nutr. Sci. Vitaminol. 2003, 49, 217-220. [CrossRef] [PubMed]

25. Odubanjo, V.O.; Olasehinde, T.A.; Oyeleye, S.I.; Oboh, G.; Boligon, A.A. Seed extracts from Myristicafragrans (nutmeg) and Moringa oleifera (drumstick tree) inhibits enzymes relevant to erectile dysfunction and metal-induced oxidative damage in rats' penile tissues. J. Food Biochem. 2017, 1, e12452. [CrossRef]

26. Sharma, M.; Levenson, C.; Browning, J.C.; Becker, E.M.; Clements, I.; Castella, P. East Indian sandalwood oil is a phosphodiesterase inhibitor: A new therapeutic option in the treatment of inflammatory skin disease. Front. Pharmacol. 2018, 9, 1-12. [CrossRef]

27. El-Ahmady, S.H.; Ashour, M.L.; Wink, M. Chemical composition and anti-inflammatory activity of the essential oils of Psidiumguajava fruits and leaves. J. Essent. Oil Res. 2013, 25, 475-481. [CrossRef]

28. Demirci, F.; Karaca, N.; Tekin, M.; Demirci, B. Anti-inflammatory and antibacterial evaluation of Thymussipyleus boiss. subsp. sipyleus var. sipyleus essential oil against rhinosinusitis pathogens. Microb. Pathogenesis. 2018, 122, 117-121. [CrossRef] [PubMed]

29. Li, W.; Fan, T.; Zhang, Y.; Fan, T.; Zhou, P.; Niu, X. Houttuyniacordata thunb. volatile oil exhibited anti-inflammatory effects in vivo and inhibited nitric oxide and tumor necrosis factor-alpha production in LPS-stimulated mouse peritoneal macrophages in vitro. Phytothe. Res. 2013, 27, 1629-1639. [CrossRef]

30. Oliveira, M.L.M.; Nunes-Pinheiro, D.C.S.; Bezerra, B.M.O.; Leite, L.O.; Tomé, A.R.; Girão, V.C.C. Topical Anti-inflammatory Potential of Pumpkin (Cucurbitapepo L.) Seed Oil on Acute and Chronic Skin Inflammation in Mice. Acta Sci. Veter. 2013, 41, 1-9.

31. AOAC. Official Methods of Analysis of AOAC International, 19th ed.; Association of Official Analytical Chemists: Washington, DC, USA, 2000.

32. Lau, H.L.N.; Puah, C.W.; Choo, Y.M.; Ma, A.N.; Cheng, H.C. Simultaneous quantification of free fatty acids, free sterols, squalene, and acylglycerol molecular species in palm oil by high-temperature gas chromatography-flame ionization detection. Lipids 2005, 40, 523-528.

33. Yasamin, S.; Mohammad, A.S.; Mohsen, B. Influence of processing parameters on physicochemical properties of fractionated fish oil at low temperature crystallization. Nutr. Food Sci. 2015, 45, 2-19.

34. Nayik, G.A.; Dar, B.N.; Nanda, V. Optimization of the process parameters to establish the quality attributes of DPPH radical scavenging activity, total phenolic content, and total flavonoid content of apple (Malusdomestica) honey using response surface methodology. Inter. J. Food Prop. 2016, 19, 1738-1748. [CrossRef]

35. Segovia, F.J.; Hidalgo, G.I.; Villasante, J.; Ramis, X.; Almajano, M.P. Avocado Seed: A Comparative Study of Antioxidant Content and Capacity in Protecting Oil Models from Oxidation. Molecules 2018, $23,2421$. [CrossRef] [PubMed]

36. Mamillapalli, R.; Haimovitz, R.; Ohad, M.; Shinitzky, M. Enhancement and inhibition of snake venom phosphodiesterase activity by Iysophospholipids. FEBSLett. 1998, 436, 256-258. [CrossRef] 
37. Carrasco, A.; Ortiz-Ruiz, V.; Martinez-Gutierrez, R.; Tomas, V.; Tudela, J. Lavandulastoechas essential oil from Spain: Aromatic profile determined by gas chromatography-mass spectrometry, antioxidant and lipoxygenase inhibitory bioactivities. Ind. Crop. Prod. 2015, 73, 16-27. [CrossRef]

38. Sukhotnik, I.; Moati, D.; Shaoul, R.; Loberman, B.; Pollak, Y.; Schwartz, B. Quercetin prevents small intestinal damage and enhances intestinal recovery during methotrexate-induced intestinal mucositis of rats. Food Nutr. Res. 2018, 62, 1327. [CrossRef] [PubMed]

Sample Availability: Samples of the compounds are available from the authors.

(C) 2019 by the authors. Licensee MDPI, Basel, Switzerland. This article is an open access article distributed under the terms and conditions of the Creative Commons Attribution (CC BY) license (http://creativecommons.org/licenses/by/4.0/). 